\title{
Nitrogen loss mitigation using duration-controlled grazing: Field observations compared to modelled outputs
}

\author{
C.L. CHRISTENSEN, M.J. HEDLEY, J.A. HANLY and D.J. HORNE \\ Fertilizer \& Lime Research Centre, Massey University, Private Bag 11222, Palmerston North
}

C.L.Christensen@massey.ac.nz

\begin{abstract}
Dairy farmers in New Zealand are encouraged to adopt a range of management strategies, both well established and emerging, to reduce nitrogen $(\mathrm{N})$ losses to waterways. In most regions the OVERSEER ${ }^{\circledR}$ nutrient budgeting software (Version 6) (hereafter referred to as Overseer) is the tool of choice in the assessment of $\mathrm{N}$ losses for both regulatory and monitoring purposes. As part of these processes, Overseer is used to assess the impact of improved farm practices on $\mathrm{N}$ leaching and runoff from individual farms. In a 3-year dairy system field trial at Massey University, $\mathrm{N}$ losses in leaching and runoff under duration-controlled grazing $(D C ; 4$ hours per grazing) were compared with those under standard grazing ( $S G ; 7$ hours per day-grazing, 13 hours per night-grazing). A $36 \%$ reduction in total nitrogen (TN) losses under $D C$ grazing was measured (14 kg TN/ha) relative to standard grazing $(22 \mathrm{~kg} \mathrm{TN} / \mathrm{ha})$. Farmers adopting $D C$ grazing as a mitigation strategy will only be able to claim the reduction in TN losses estimated by Overseer, and thus observations from the field trial were compared with outputs from Overseer. There was good agreement between the Overseer predictions of $\mathrm{N}$ leaching and values measured at the trial site for both the $S G$ and $D C$ grazing treatments. A second Overseer simulation of a $D C$ system suggests that while Overseer is able to predict the reductions in $\mathrm{N}$ leaching under $D C$ grazing reasonably well, some issues such as runoff losses and storage of effluent need further consideration. Keywords: Duration-controlled grazing; OVERSEER $^{\circledR}$; $\mathrm{N}$ leaching
\end{abstract}

\section{Introduction}

The New Zealand dairy industry is striving for increased productivity and a smaller environmental footprint, with particular emphasis on decreasing nutrient losses to waterways (PCE 2012). A modelling exercise conducted by Monaghan et al. (2008) identified a number of farm management strategies that effectively reduce the amounts of nitrate leached from dairy farms. One of these strategies involved restricting the grazing hours of cows in autumn and winter. This strategy is effective if it can reduce the deposition of urinary nitrogen $(\mathrm{N})$ in concentrated patches in the paddock and instead collect that urine when the cow is stood-off the pasture and return it at a uniformly low rate. The potential of restricted grazing as a strategy to reduce losses of $\mathrm{N}$, phosphorus (P) and faecal microbes from dairy farms to surface water was tested in a field study at Massey University over 3 years (Christensen et al. 2012). Duration-controlled grazing ( $D C$ grazing), is a year-round management system that aims to utilise pasture in situ, but limits the time that cows spend grazing paddocks to 8 hours per 24-hour period, with the remaining 14 hours spent on stand-off facilities. The effects of this system on pasture production and losses of N, P and faecal microbes have been measured.

This paper will compare the field trial results from $D C$ grazing trial with simulations of this system by OVERSEER $^{\circledR}$ nutrient budgeting software (Version 6) (hereafter referred to as Overseer). Differences will be discussed, and consideration will be given to how field data can be used for further development of the modelling software.

\section{Methods}

\section{Trial site}

The 3-year field trial, established in 2008, was conducted on Massey University's No. 4 Dairy Farm near Palmerston North, Manawatu, New Zealand $\left(40^{\circ}\right.$ $\left.23^{\prime} 46.79^{\prime \prime} \mathrm{S} ; 175^{\circ} 36^{\prime} 35.77^{\prime \prime} \mathrm{E}\right)$. The trial site was located in a flat landscape ( $c a .<3 \%$ slope), which receives an average annual rainfall of approximately $1000 \mathrm{~mm}$. The site had a mixed pasture sward of predominantly perennial ryegrass (Lolium perenne) and white clover (Trifolium repens). The trial was established on a mole-pipe drained Tokomaru silt loam soil, which is classified as a Fragic Perch-gley Pallic Soil (Hewitt 1998).

The research area consisted of 14 plots $\left(c a .850 \mathrm{~m}^{2} /\right.$ plot), each with an isolated mole and pipe drain system. Mole channels, $c a .40 \mathrm{~m}$ long, were installed at a depth of $0.45 \mathrm{~m}$ and spaced $2 \mathrm{~m}$ apart. Drainage from the mole channels was intercepted by a perforated pipe drain $(0.11 \mathrm{~m}$ diameter) installed perpendicular to the moles at a depth of $0.60 \mathrm{~m}$. Further description of the topography and soil properties of the site can be found in Houlbrooke et al. (2004).

Within each grazing plot there was also a $50 \mathrm{~m}^{2}$ surface runoff sub-plot, isolated on three sides by buried 
wooden boards and grading to a gutter on the fourth side to collect storm surface runoff. The runoff was then directed to a tipping bucket water flow recorder and sampler.

\section{Experimental design}

The trial consisted of two treatments. The standard grazing $(S G)$ treatment plots involved a grazing duration of $c a .7$ hours for day-grazings and $c a .13$ hours for night-grazings. The other treatment was durationcontrolled grazing $(D C)$, which involved plots with a grazing duration of $c a .4$ hours for both day and night grazings. All plots were grazed on the same day with the same average stocking rate, which was set according to pasture cover (as estimated using a rising-plate pasture height meter). Grazings alternated between "day" and "night" regimes to simulate standard farm practice. There were $8-10$ grazings per year.

The trial site was established during the summer of 2008. For fertiliser applications, drainage dates, and cow feeding regimes refer to Christensen et al. (2012), and Table 1.

\section{Estimated dung deposition and slurry application}

The dung pats deposited on each plot were counted to give an indication of the total amount of excreta returned to the plots. The difference in annual average dung depositions between the two treatments was used to estimate the quantity of excreta that would be transferred to the standoff facility and therefore the amount of slurry to be applied to the $D C$ treatment. The model of Salazar et al. (2010), which is based on herbage intake and $\mathrm{N}$ concentration, was also used to estimate the amount of excreta returned to the plots. The estimate of excreta transferred to the standoff facility by the Salazar model (Table 2 ) was very similar to the estimate given by counting dung pats. Based on the observations of Longhurst et al. (2006) that $45 \%$ of the dung plus urine $\mathrm{N}$ could be lost in storage over a period of 3 months, the long-term annual average slurry application to the $D C$ plots was planned to deliver approximately $55 \%$ of the difference in $\mathrm{N}$ deposited on the $S G$ plots compared with the $D C$ as urine and dung. In mid-December 2008, slurry, derived from a feedpad bunker with a weeping wall, was first applied to the $D C$ plots $(212 \mathrm{~kg} \mathrm{~N} / \mathrm{ha})$ at twice the annual application $\mathrm{N}$ rate in dry soil conditions (Christensen et al. 2012). This represented a biennial application and was the only application of slurry in the 2008/09 season: no slurry was applied during the second lactation season. Four lighter applications totalling $115 \mathrm{~kg} \mathrm{~N} / \mathrm{ha}$ were applied to $D C$ plots in the third season (Table 2).

\section{Drainage water volume measurements and water analysis}

Drainage and surface runoff water from plots was channelled through drainage pipes into tipping-bucket flow meters located in sampling pits nearby. Each tipping-bucket was calibrated dynamically to account for slightly larger tip volumes at greater flow rates. All tipping buckets were instrumented with data loggers to provide continuous measurements of flow rate. During each drainage and surface runoff event, a proportion (ca. $0.1 \%$ ) of the water from every second tip of the tipping bucket was automatically collected to provide a volume-proportional sample for water quality analysis.

Table 1: $\quad$ Parameters entered into Overseer (based on Massey No 4 Dairy Farm) for both SG and MDC treatment systems

Cow numbers / Breed / Total farm area

Total milk solids production

\section{Supplements Imported (all on DM basis)}

( $S G$ fed on feed pad for 1 hour per day during lactation;

$D C$ fed in covered animal shelter with 8 hours grazing per day)

Average rainfall

Soil type / drainage

Fertiliser inputs (kg/ha; month)
630 / FxJ / 211 ha

$226800 \mathrm{~kg} / \mathrm{yr}$

Maize silage (180 t/yr)

Triticale silage (90 t/yr)

Pasture silage (120 t/yr)

Hay (15 t/yr)

Palm kernel meal $(40 \mathrm{t} / \mathrm{yr})$

$980 \mathrm{~mm} / \mathrm{yr}$

Tokomaru silt loam / mole \& pipe drained

Sulphur super 30 (200 kg/ha; March)

Urea (38 kg/ha; April)

Ammonium sulphate $(71 \mathrm{~kg} / \mathrm{ha}$; October $)$

Ammonium sulphate $(71 \mathrm{~kg} / \mathrm{ha}$; November)

Urea (76 kg/ha; December)

$40 \%$ cows off 1 June to 31 July

Olsen P (mg/l) QTK $\mathrm{SO}_{4}-\mathrm{S}(\mathrm{mg} / \mathrm{kg})$

30 
Unfiltered water samples were digested using the alkali persulphate method of Hosomi \& Sumo (1986). They were then analysed using colorimetric methods on a Technicon Auto Analyser (Blakemore et al. 1987), to give concentrations of total nitrogen (TN), including organic and mineral components.

\section{Comparison of measured $v s$. modelled losses}

Data describing the $S G$ management regime was entered into Overseer (Version 6; Web version accessed 13 September 2012) (Table 1). A DC system was also modelled in Overseer (hereafter called the $M D C 1$ system). Many of the input parameters for the $M D C 1$ system were based on the field trial e.g., the inclusion of a covered animal shelter as the standoff area, with 8 hours per day grazing, and $100 \%$ of the on-farm cows using the animal shelter year-round. In the Overseer simulation, the pad was scraped (without water) and the effluent kept separate from the farm dairy effluent system. Subsequently, the majority of the "MDCl" farm had animal shelter effluent applied to it, the liquid being sprayed infrequently, and the solids being applied four times per year (November, December, February and April). The quantity of imported supplementary feed and manufactured fertiliser, cow numbers and milksolids production were the same as values used in the $S G$ system (Table 1).

In a second exercise, the inputs to Overseer were modified so as to more closely represent effluent return to the $D C$ plots in the field trial (MDC2). This allowed for an assessment of the agreement between an Overseer prediction of $\mathrm{N}$ losses from a durationcontrolled grazing system and measured values.

\section{Results \& Discussion}

Measured total nitrogen (TN) leaching losses from the $S G$ treatment were 18,13 and $26 \mathrm{~kg} \mathrm{~N} / \mathrm{ha} / \mathrm{yr}$ (average of $19 \mathrm{~kg} \mathrm{~N} / \mathrm{ha} / \mathrm{yr}$ ) for the years 2009,2010 and 2011, respectively. The variation in leaching values across the 3 years is partly explained by differences in drainage patterns. Although total drainage amounts were similar over the 3 years $(373 \mathrm{~mm}, 316 \mathrm{~mm}$ and $329 \mathrm{~mm}$ ), the initiation and length of the drainage seasons varied. Furthermore, the concentrations of $\mathrm{NO}_{3}^{-}-\mathrm{N}$ in drainage water, making up on average $64 \%$ of the TN concentration, varied markedly with length of drainage season (Christensen et al. 2012). This was expected due to the seasonal nature of $\mathrm{N}$ availability and pasture uptake, and the coincidence of grazing and drainage events (Houlbrooke 2005).

TN leaching losses of 13,7 and $14 \mathrm{~kg} \mathrm{~N} / \mathrm{ha} / \mathrm{yr}$ (average $11 \mathrm{~kg} \mathrm{~N} / \mathrm{ha} / \mathrm{yr}$ ) were measured from the $D C$ treatment. Compared to the $S G$ treatment, this translates into a reduction in TN leaching of $28 \%, 46 \%$ and $46 \%$ over the three years, 2009, 2010 and 2011, respectively. This equated to a $42 \%$ reduction on average, which exceeds the Dairy Industry's goal of a 30\% reduction in $\mathrm{N}$ leaching losses (DairyNZ 2010).

When the surface runoff losses $(3.2 \mathrm{~kg} \mathrm{~N} / \mathrm{ha}$ for $S G$ and $2.9 \mathrm{~kg} \mathrm{~N} / \mathrm{ha}$ for $D C$ ) were added to the leaching losses, the average overall TN losses to water for the $S G$ treatment was $22 \mathrm{~kg} \mathrm{~N} / \mathrm{ha} / \mathrm{yr}$, compared with 14 $\mathrm{kg} \mathrm{N} / \mathrm{ha} / \mathrm{yr}$ for the $D C$ treatment (a $36 \%$ reduction). Therefore, on average $83 \%$ of TN losses were through drainage, which is consistent with the values measured by Houlbrooke (2005) at the same site.

Table 2: $\quad$ The estimated annual return of $\mathrm{N}$ in dung and urine to $D C$ and $S G$ treatments, the theoretical target slurry application, the difference in $\mathrm{N}$ returned to $D C$ plots, the actual return of $\mathrm{N}$ in slurry, and Overseer predictions (kg N/ha/yr).

\begin{tabular}{|c|c|c|c|c|c|c|c|}
\hline \multicolumn{2}{|l|}{ Year } & $\begin{array}{c}\text { Amount } \mathrm{N} \\
\text { estimated } \\
\text { returned as } \\
\text { dung and urine }{ }^{1}\end{array}$ & \multirow[t]{2}{*}{$\begin{array}{l}\text { Theoretical } \\
\text { target slurry } \\
\text { application }{ }^{1,2}\end{array}$} & \multirow{2}{*}{$\begin{array}{c}\begin{array}{c}\text { Fertiliser } \\
\text { applied (3-yr } \\
\text { annual average) }\end{array} \\
60\end{array}$} & \multirow{2}{*}{$\begin{array}{c}\text { Total } \mathrm{N} \\
\text { theoretically } \\
\text { returned }\end{array}$} & \multirow[t]{2}{*}{$\begin{array}{l}\text { Theoretical } \\
\text { difference in } \\
\mathrm{N} \text { returned } \\
\text { to } \mathrm{DC} \text { plots }\end{array}$} & \multirow[t]{2}{*}{$\begin{array}{l}\text { Actual } N \\
\text { application in } \\
\text { form of slurry }\end{array}$} \\
\hline $2008 / 09$ & SG & 383 & & & & & \\
\hline & $\mathrm{DC}$ & 155 & 136 & 60 & 351 & -92 & $212^{3}$ \\
\hline \multirow[t]{2}{*}{$2009 / 10$} & SG & 340 & & 100 & 440 & & \\
\hline & $\mathrm{DC}$ & 137 & 121 & 100 & 358 & -82 & nil \\
\hline \multirow[t]{2}{*}{$2010 / 11$} & SG & 425 & & 85 & 510 & & \\
\hline & $\mathrm{DC}$ & 172 & 151 & 85 & 408 & -102 & 115 \\
\hline Ave & SG & 383 & & 82 & 464 & & \\
\hline Ave & $D C$ & 155 & 136 & 82 & 372 & -92 & 109 \\
\hline Overseer & & & 176 & 82 & & & \\
\hline
\end{tabular}

${ }^{1}$ Estimated using modified version of model by Salazer et al. (2010) based on number of grazings in each year and average herbage $\mathrm{N}$ concentrations.

${ }^{2}$ Assuming $45 \%$ losses of $\mathrm{N}$ from animal shelter, based on Longhurst (2006).

${ }^{3}$ Biennial strategy of slurry application. 
When the $S G$ treatment data was entered into Overseer, the $\mathrm{N}$ loss to water for $S G$ grazing was estimated to be $23 \mathrm{~kg} \mathrm{~N} / \mathrm{ha} / \mathrm{yr}$, which was slightly higher than the 3-year measured average value for the $S G$ plots ( $22 \mathrm{~kg} \mathrm{~N} / \mathrm{ha} / \mathrm{yr})$. While these losses were very close, Overseer predicted that all of the $\mathrm{N}$ lost to water was as leaching and no $\mathrm{N}$ was lost as runoff. Whereas, $3.2 \mathrm{~kg} \mathrm{~N} /$ ha was measured in runoff in the field study.

In order to predict $\mathrm{N}$ losses to water, Overseer simulates $\mathrm{N}$ transfer via dung, urine and effluent streams and predicts the $\mathrm{N}$ loss outcome associated with grazing and effluent management. The $D C$ grazing strategy reduces the urine deposition to paddocks and uniformly applies the captured excreta as a slurry or effluent - all of these processes can be simulated within Overseer's model framework.

The Overseer simulation of the $M D C 1$ system predicted an average TN loss to water of $14 \mathrm{~kg} \mathrm{~N} / \mathrm{ha} /$ $\mathrm{yr}$, which was, in general terms, similar to the average loss measured in the trial for this treatment. Again, Overseer predicted that all of the loss to water was as leaching, with no runoff losses of N, compared to a 2.9 $\mathrm{kg} \mathrm{N} / \mathrm{ha}$ runoff loss measured in the study.

In the Overseer prediction for the $M D C 1$ system, the annual average effluent application was $176 \mathrm{~kg} \mathrm{~N} / \mathrm{ha} / \mathrm{yr}$. It is notable that the theoretical (Salazer et al. 2010) and measured effluent return to the $D C$ plots averaged 136 and $109 \mathrm{~kg} \mathrm{~N} / \mathrm{ha} / \mathrm{yr}$, respectively (Table 2). However, the long-term average return of effluent $\mathrm{N}$ predicted by Overseer at $176 \mathrm{~kg} \mathrm{~N} / \mathrm{ha} / \mathrm{yr}$ was 40 and $67 \mathrm{~kg} \mathrm{~N} /$ ha/yr above the theoretical target and measured slurry returns.

One possible reason for the difference between estimated and measured $\mathrm{N}$ returns in effluent/slurry is that Overseer may assume smaller $\mathrm{N}$ losses in storage than the Longhurst et al. (2006) values, which were used in the theoretical calculations. $\mathrm{N}$ losses during storage are difficult to predict, not least of all because of variation in storage time between farms.

In the second exercise, the Overseer simulation of the $M D C$ system was modified ( $M D C 2$ ) so as to deliver $109 \mathrm{~kg} \mathrm{~N} / \mathrm{ha} / \mathrm{yr}$ as effluent (i.e., to approximate the $D C$ treatment at the field trial). This was achieved by keeping all other parameters the same as the $M D C 1$ system but increasing the covered storage time of the animal shelter effluent solids to 36 months. With an effluent application of $109 \mathrm{~kg} \mathrm{~N} / \mathrm{ha}$, Overseer predicted $\mathrm{TN}$ losses to water from the system at $10 \mathrm{~kg} \mathrm{~N} / \mathrm{ha} / \mathrm{yr}$ from leaching and $0 \mathrm{~kg} \mathrm{~N} / \mathrm{ha} / \mathrm{yr}$ from runoff, compared with the field measurements of $11 \mathrm{~kg} \mathrm{~N} / \mathrm{ha} / \mathrm{yr}$ from leaching and $3 \mathrm{~kg} \mathrm{~N} / \mathrm{ha} / \mathrm{yr}$ from runoff. This result shows that when the $\mathrm{N}$ returned to pasture in effluent was adjusted in Overseer to equal the average returns in the trial ( $109 \mathrm{~kg} \mathrm{~N} / \mathrm{ha} / \mathrm{yr})$, then the $\mathrm{N}$ leaching predicted by Overseer was in good agreement with the measured values. However, Overseer did not predict the runoff $\mathrm{N}$ losses measured in the trial. Runoff is inherently difficult to model, particularly from annual average inputs, due to the different factors that influence these losses.

There is general agreement between $\mathrm{N}$ losses to water in Overseer and the results seen in the field trial. Overseer was able to predict the $\mathrm{N}$ leaching loss reductions achievable using the $D C$ mitigation strategy, which demonstrates that it has been partially updated to reflect the results from research of mitigation strategies (Overseer 2012), such as using animal shelters. An important point to take from this work is that measured $\mathrm{N}$ loss to water varied by $c a$. $50 \%$ for both treatments between the three years. Overseer's attempt at predicting the long-term average $\mathrm{N}$ loss to water for the $S G$ treatment was within $1 \mathrm{~kg} \mathrm{~N} / \mathrm{ha} / \mathrm{yr}$, and the model did predict the large reduction from $D C$ plots, within 4 $\mathrm{kg} \mathrm{N} / \mathrm{ha} / \mathrm{yr}$. While $4 \mathrm{~kg}$ is a large percentage difference in this situation, the important aspect remains the large reduction caused by the mitigation, and reflected in the Overseer predictions.

However, there remains uncertainty surrounding the simulation of $\mathrm{N}$ returned as stored effluent and $\mathrm{N}$ losses in runoff. It is important for the quantities of effluent $\mathrm{N}$ returned to pastures in $D C$ grazing systems to be accurately estimated because a much larger proportion of nutrients are returned to pastures as effluent compared to standard grazing practice. Further, farmscale research of $D C$ grazing systems is required to provide improved understanding of nutrient dynamics in stored effluent and the quantity of nutrients actually returned to pastures in these systems.

\section{Conclusion}

In a 3-year field trial at Massey University, durationcontrolled grazing resulted in a $36 \%$ reduction in total nitrogen (TN) losses (leaching plus runoff) relative to a standard dairy grazing system. When a durationcontrolled system was modelled using Overseer $(M D C 1)$, the predicted reduction in $\mathrm{TN}$ losses was $39 \%$ compared with a standard grazing system. When $D C$ grazing as practised at the field trial was simulated with Overseer (MDC2), there was good agreement with measured values for $\mathrm{N}$ leaching.

Overseer (Version 6) seems to predict $\mathrm{N}$ leaching losses under $D C$ grazing reasonably well. Issues that require further consideration in Overseer relate to the proportion of TN losses in runoff, and the quantity of $\mathrm{N}$ returned to pastures in effluent collected from stand-off facilities. 


\section{ACKNOWLEDGEMENTS}

This field study was conducted through the Pastoral 21 Environment Programme (C10X0603), a collaborative venture between DairyNZ, Fonterra, Dairy Companies Association of New Zealand, Beef + Lamb NZ and the Ministry of Business, Innovation and Employment. Thank you to the staff of No. 4 Dairy Farm, and a special thank you to the Fertilizer and Lime Research Centre technical team for their assistance with field and laboratory work.

\section{REFERENCES}

Blakemore, L.C.; Searle, P.L.; Daly, B.K. 1987. Methods for chemical analysis of soils. New Zealand Soil Bureau Scientific Report 80.

Christensen, C.L.; Hedley, M.J.; Hanly, J.A.; Horne, D.J. 2012. Three years of duration-controlled grazing: What have we found? In: Advanced Nutrient Management: Gains from the past, goals for the future, Occasional Report No. 25. Eds Currie, L.D.; Christensen, C.L. Fertilizer \& Lime Research Centre, Palmerston North.

DairyNZ 2010. Dairy Industry Strategy - directions to the vision. Hamilton, NZ

Hewitt, A.E. 1998. NZ Soil Classification (2 edn). Manaaki Whenua - Landcare Research New Zealand Ltd Press: Lincoln

Hosomi, M.; Sudo, R. 1986. Simultaneous determination of total nitrogen and total phosphorus in freshwater samples using persulfate digestion. International Journal of Environmental Studies 27: 267-275.

Houlbrooke, D.J. 2005. A study of the quality of articificial drainage under intensive dairy farming and the improved management of farm dairy effluent using 'deferred irrigation'. PhD Thesis, Massey University, Palmerston North
Houlbrooke, D.J.; Horne, D.J.; Hedley, M.J.; Hanly, J.A.; Scotter, D.R.; Snow, V.O. 2004. Minimising surface water pollution resulting from farm-dairy effluent application to mole-pipe drained soils. I. An evaluation of the deferred irrigation system for sustainable land treatment in the Manawatu. New Zealand Journal of Agricultural Research 47: 405415.

Longhurst, R.D.; Luo, J.; O'Connor, M.B.; Pow, T. 2006. Herd Homes: nutrient management and farmer perceptions of performance. Proceedings of the New Zealand Grassland Association 68: 309-313.

Monaghan, R.M.; de Klein, C.A.M.; Muirhead, R.W. 2008. Prioritisation of farm scale remediation efforts for reducing losses of nutrients and faecal indicator organisms to waterways: A case study of New Zealand dairy farming. Journal of Environmental Management 87: 609-622.

Overseer (2012). Changes to the pastoral N model Technical Note No. 5.

PCE 2012. Water Quality in New Zealand: Understanding the Science. Parliamentary Commissioner for the Environment, Wellington, NZ.

Salazer, M.E.; Hedley, M.J.; Horne, D.J. 2010. Using turnips to reduce soil $\mathrm{K}$ loading on the effluent block. Proceedings of the New Zealand Grassland Association 72: 247-250. 
